Article

\title{
Municipal Efforts to Reduce Greenhouse Gas Emissions: Evidence from U.S. Cities on the U.S.-Mexico Border
}

\author{
Sylvia Gonzalez-Gorman ${ }^{1, *} \mathbb{C}$, Sung-Wook Kwon ${ }^{2} \mathbb{C}$ and Dennis Patterson ${ }^{2}$ \\ 1 Department of Political Science, University of Texas Rio Grande Valley, Edinburg, TX 78539, USA \\ 2 Department of Political Science, Texas Tech University, Lubbock, TX 79409, USA \\ * Correspondence: sylvia.gonzalezgorman@utrgv.edu
}

Received: 29 June 2019; Accepted: 26 August 2019; Published: 31 August 2019

\begin{abstract}
In this study, we examine municipal efforts to reduce greenhouse gas emissions (GHG) by focusing on emissions from vehicular sources. We compare what different cities have done to address the problem of GHG emissions from vehicles by using atmospheric data to assess the impact policy efforts have had on actual GHGs. We focus on an area overlooked in the literature, U.S. cities on the U.S.-Mexico transborder region. Using GHG vehicular emissions data from the Center for Neighborhood Technology (CNT) and an ordinary least square model, this research foundcities have reduced levels of GHGs, especially when municipal efforts are supported by state policies to reduce GHG emissions. While GHG in general are transboundary and a global issue by nature, communities in the U.S. border region are directly impacted by vehicular emissions due to cross-border trade that is not prevalent in interior communities. However, one of the main limitations in this type of study is the lack of reportable environmental data for less populated cities on the U.S.-Mexico border. Future studies need to develop alternative approaches to sustainability that could provide a more nuanced examination of some of the challenges or success in the U.S. transborder region.
\end{abstract}

Keywords: transborder region; greenhouse gas emissions; economic development; climate action plan (cap)

\section{Introduction}

In a recent essay in Foreign Affairs, former New York City Mayor, Michael Bloomberg, made a compelling case for why municipalities would take the lead in combatting the deleterious impacts of global climate change [1]. While his essay can certainly be characterized as a call to action, it also pointed to the fact that, over the past 40 years, cities in the United States have implemented various policies to contend with climate change by working to reduce greenhouse gas (GHG) emissions [2-4]. While some cities have taken action on their own and others have acted in concert with state policies that encouraged the reduction of GHG emissions, scholars have examined these policy efforts, and the result is a growing body of scholarly research on how cities have taken the lead in promoting sustainable practices and reducing GHG emissions.

Most of the research we have on municipal efforts thus far has involved inventories and comparisons of different city policies to operate in a sustainable fashion and to reduce GHG emissions, but the focus has been limited to actions taken by the largest cities in the interior United States. Our purpose in this paper is to continue this tradition of research, but in a way that is distinct from current efforts. We accomplish this by focusing on a collection of cities that have not received much attention in the scholarly literature on GHG emission reductions. Specifically, we examine cities on the U.S.-Mexico transborder region and their efforts to reduce GHG emissions. We also compare and evaluate their 
policy efforts to cities elsewhere in the United States. In addition to this, we take the additional step in this effort to assess the actual impacts of municipal policy efforts to reduce GHG emissions in the U.S. transborder region by including not just the region's largest cities, but all of the region's cities, which are not well represented in extant studies.

Cities on the U.S. side of the transborder region with Mexico, especially smaller cities, represent an interesting sample for this type of investigation. These cities exist in four very different states that border the country of Mexico, which means that they are very different from communities in the interior of the United States [5]. More importantly, U.S. cities in the U.S.-Mexico transborder region have received very little attention in terms of environmental degradation studies. Part of the problem is that, despite sharing a common border, these transborder cities are characterized by a wide variety of population sizes and urban densities, and they are also distinct in terms of their respective social and economic profiles. In addition to this, American cities on the U.S.-Mexico border are also distinguished from one another in that they have fostered their own traditions, cultures, and policy priorities, but with respect to environmental concerns, they are alike because they share a common ecological environment, specifically, air basins, watersheds and rivers [5]. Thus, environmental degradation on one side of the border will carry ecological consequences for local communities on the other side.

By way of illustration, consider the fact that, in 2016, 75.6 million in-bound personal vehicles crossed into the United States [6], directly impacting the environmental conditions of U.S. transborder cities. By 2017, the number of in-bound personal vehicles grew to over 77 million [6]. More significantly, these numbers do not include in-bound and out-bound freight vehicles that regularly idle for several hours at U.S.-Mexico ports of entry where several U.S. transborder cities exist. Simply stated, in addition to border cities being different in terms of their economic and political wherewithal to deal with the impacts of GHG emissions, the incentives they face for acting to reduce these emissions are complicated by a collective action problem. Specifically, cities on one side of the border face disincentives when implementing policies to reduce GHG emissions because a lack of action on the other side can reduce or even negate any positive impact such policy efforts may have [7]. Moreover, because these cities have not been uniform in their policy efforts, policies are still deficient and environmental conditions such as strained water supplies, inadequate waste management, and pollution continue to exist in many transborder areas.

Despite such disincentives, U.S. transborder cities, like those in other parts of the United States, have implemented numerous policies to address the environmental problems they face and specifically to reduce GHG emissions. The policy actions that have been taken by these cities have naturally been motivated by the fact that environmental concerns between the United States and Mexico are significant and have been well established in the scholarly literature $[8,9]$. Nonetheless, as stated above, scholarly attention to communities in the U.S. transborder region has been minimal, because most attention has focused on large metropolitan statistical areas (MSA) such as El Paso, San Diego, and Tucson, which are routinely examined for their environmental programs. Again, while we know that border cities have taken action to address the negative impacts of global climate change $[5,10,11]$, there is still room for additional research on what actions U.S. transborder cities have taken specifically to reduce GHG emissions and what impact these differential efforts have had on ambient air quality in the region. We fill this gap in this paper by examining communities on the U.S.-Mexico border, which include sparsely populated U.S. border communities such as Desert Shores, CA, La Union, NM, and Valentine, TX.

We will accomplish this by developing and estimating a statistical model that weights the various policy actions taken by local governments in this region on actual levels of GHG in the atmosphere from vehicular, nonpoint sources. We consider the impact of several geographic and socioeconomic factors as well as indicators of actual policy actions taken by cities in this region across the four states. We begin this effort with a discussion of the communities that are the target of this research, specifically, cities on the U.S. side of the U.S.-Mexico transborder region and their efforts to reduce GHG emissions from vehicles. 


\section{Theoretical Argument: Greenhouse Gas Reduction Efforts along the U.S.-Mexico Border}

A 2,000-mile border from the Pacific Ocean to the Gulf of Mexico separates the United States and Mexico. This international divide converges on four U.S. states and six Mexican states. The $1983 \mathrm{La}$ Paz Agreement defined the transborder region as all territory lying 62.15 miles $(100 \mathrm{~km})$ on each side of the international border (Figure 1). This was, the first bilateral cooperation program on issues of environmental quality along the U.S.-Mexico border, and because of the La Paz Agreement, working groups were established to address water and air quality, solid waste, and other environmental issues that continue to persist in the border region. In 2004, the designation of the transborder region was amended through the Border Environment Cooperation Commission (BECC) and North American Development Bank (NADB) charter to expand the transborder region $300 \mathrm{~km}$ into Mexico, but with no change to the U.S. side.

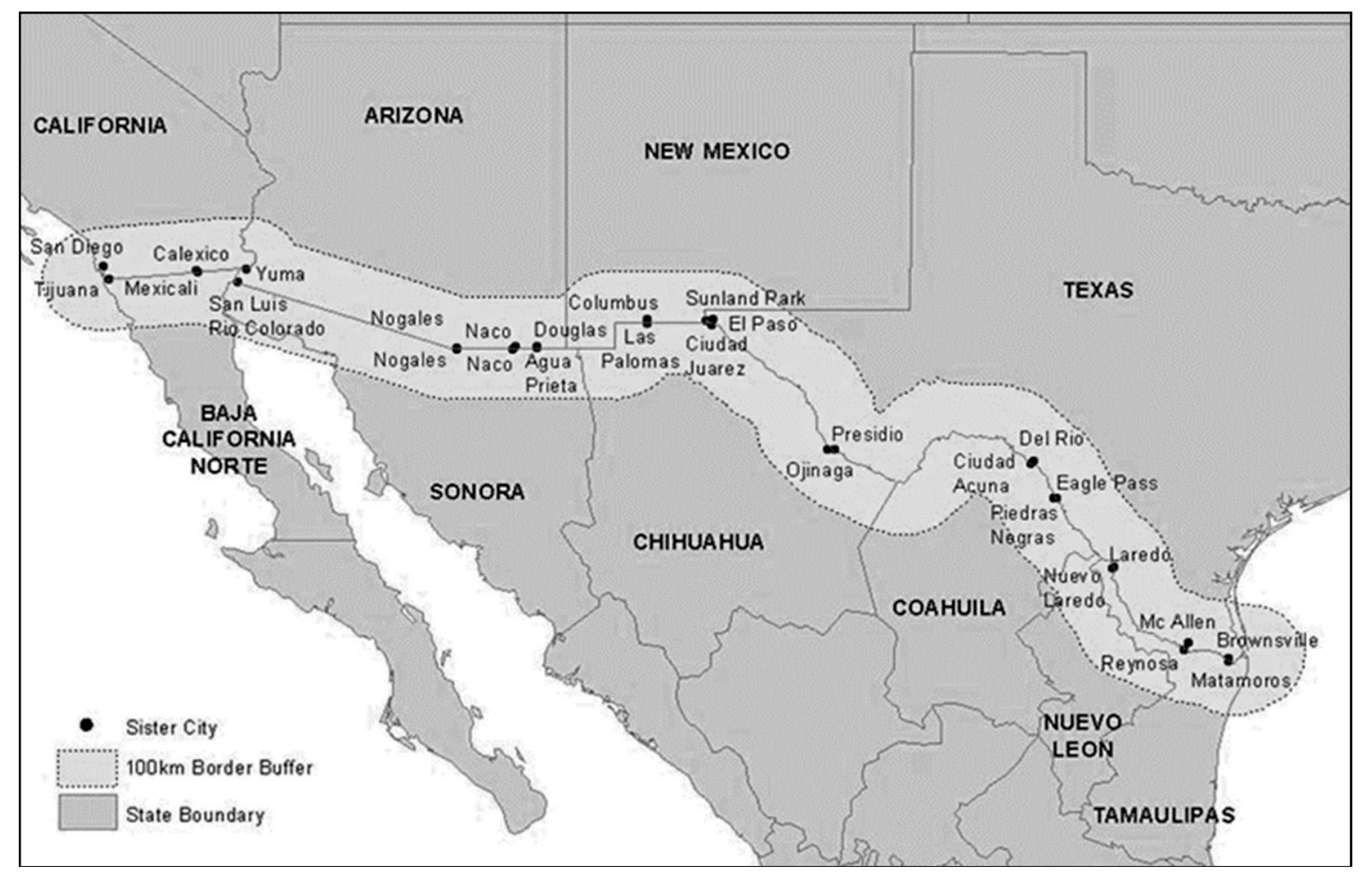

Figure 1. Cities on the United States-Mexico Border. Source: Environmental Protection Agency, U.S.-Mexico Border 2020 Program. https://www.epa.gov/border2020 [12].

A point often overlooked in sustainability studies of this region is that, in response to the termination of the U.S.-Mexico brokered Bracero Program in 1964, Mexico established the Maquiladora Program in 1965. The Bracero program was established in 1942 in a bilateral agreement between the United States and Mexican government. According to this agreement, Mexico agreed to provide temporary laborers for the agriculture sector in the United States, because many U.S. agriculture growers feared a labor shortage in that sector due to higher wages being offered in factories as a result of World War II [13]. Upon termination of the Bracero Program, the Maquiladora Program was introduced as a tax-free industry that allowed the temporary importation of raw materials, supplies, and machinery for assembly and manufacturing in Mexico [14]. Upon completion, products would then be exported out of Mexico and typically back into the United States. Maquiladoras provide economic incentives to foreign assembly plants (mostly U.S. corporations) in the transborder region, which has spurred unplanned economic development in an area where the environmental protection infrastructure has lagged well behind the rest of the United States [12]. 
This region's environment was again significantly impacted in 1993 with discussions of the North American Free Trade Agreement (NAFTA), which would eliminate most trade barriers between Canada, Mexico, and the U.S. NAFTA would increase industrialization and maquiladora development between the United States and Mexico. Among other things, the results of this agreement included increasing air and water pollution for the transborder region. This is because, as industrial development and investment continued to grow so did environmental demands for natural resources, energy, and the disposal of hazardous and industrial waste [11], creating a significant ecological footprint. Even today, these problems remain unchanged, because recent policies of the Trump Administration, while leading to a renegotiation of NAFTA, they have not altered the conditions affecting the region's environment that increased under the original treaty.

Globally, the issue of reducing GHG emissions has continued to grow in salience and it has also increased in salience in the U.S.-Mexico transborder region, affecting all levels of government. Internationally, the two most important international efforts, the Kyoto Protocol and the Paris Accords, have committed national governments to reduce GHG emissions. Cities, on the other hand, have taken actions in this area mostly as part of their overall plans to operate in a cost-efficient, sustainable fashion. Municipal sustainability efforts have been around for decades, but they received international encouragement in 1987 with the issuance of the United Nations' Brundtland Commission report, Our Common Future. The Brundtland Commission [15] (p. 8) defined sustainability as "development that meets the needs of the present without compromising the ability of future generations to meet their own needs."

The Brundtland Commission's broad definition of sustainability has yielded much scholarship on the concept $[2-4,16]$. As such, scholars have continued to examine the influence of forms of local government on local sustainability actions [17-21], the relationship between sustainability agendas and cities [22,23], the effect of education levels on sustainability [4,24-26], and the effectiveness of sustainability [27]. For many U.S. cities, sustainability policies increasingly came to include efforts to reduce GHG emissions, but action to implement such policies have varied greatly across cities contemplating such policy action. The result has been notable differences across local governments. Some local governments vary their approach in adopting and implementing sustainability policies $[22,25,28,29]$. In some instances, a local government's effort to improve air quality may be muted by surrounding communities that have not incorporated sustainability agendas $[2,3,19,28]$. Importantly, reducing ground level ozone from motor vehicle exhaust, gasoline vapors, emissions from industrial facilities and electric utilizes [30] is a central tenet of sustainability, and energy efficiency is one of the primary methods for reducing GHG emissions. Since communities in the transborder region share a common ecological environment, ozone and toxic pollutants are not contained within a given boundary-they are transboundary. Due to this, implementing initiatives that reduce GHG emissions at the local level is more difficult at the U.S.-Mexico border. Even so, U.S. border communities have continued to pursue policies that aim to improve GHG emissions in their communities.

\subsection{Socio-Economic Factors and Geography and the Reduction of Greenhouse Gas Emissions}

As mentioned above, with the signing of NAFTA in 1994, trade between the United States and Mexico grew at dramatic rates. Trade between the two countries grew from $\$ 71$ billion in 1995 to an estimated $\$ 255$ billion in 2010 [31]. While this growth has slowed down with the imposition of tariffs by the Trump tariffs, growth in trade and economic activity across the U.S.-Mexico transborder region has nonetheless contributed to many cities in this region becoming more industrialized and urbanized. Naturally, this growth and economic development led to changes in many of U.S. border cities, which resulted in positive implications, including increases in employment opportunities and growing levels of prosperity. Parallel with such positive developments has been an increase in the amount of vehicular traffic within U.S. border communities themselves as well as across the U.S.-Mexico border. This has led to increases in GHG emissions from tailpipes, which has led some U.S. border cities to act to reduce these emissions. 
We know from existing research that higher levels of income are positively associated with increased political interest and efficacy because citizens with higher levels of median household income possess economic and social capital that enables them to consult with and influence elected officials [32-34]. What this means is that demand for policies that increase environmental quality may increase with income, and, as Magnani [35] has shown, higher per capita incomes result in declines in pollution emissions. While the existing literature finds a linear effect between income levels and sustainability levels, the economic characteristics of the border region require us to reexamine the shape of this well-established relationship. Cities in this region are generally characterized by depressed economic conditions, high unemployment and poverty rates, and low-income levels, when compared to the interior communities. Employment sectors in the transborder region are labor intensive, including agriculture and manufacturing as well as low-wage service industries [36]. Moreover, compared to cities in the interior of the United States, income levels in this region ranged from $\$ 12,000$ at the low end to nearly $\$ 82,000$ for the wealthiest city under examination, which is important in light of the fact that income levels are known to be a predictor of negative environmental conditions [37-40].

Taken together, these economic characteristics may result in the relationship between income and environment in the transborder region being nonlinear. Border communities where economic conditions are generally depressed and incomes are low will be subjected to less political influence demanding attention to environmental issues, providing leaders in lower income cities with fewer incentives to act to reduce GHG emissions. However, as income levels increase and cross certain threshold, citizens will become increasingly interested in the environmental problems they face and, thus, will begin advocating for policies that lead to investments in efforts to solve environmental problems, including reducing GHG emissions. While this suggests a linear relationship, the relationship may be more complicated with respect to GHG emissions from vehicles. Specifically, it may be that, as median incomes increase, individuals may be more interested in solving environmental problems, but they now have more resources to acquire additional vehicles, which will lead to increased GHG emissions from automobiles and trucks. For these reasons, it is necessary that our analysis consider statistical controls for this potential nonlinearity, and, as a result, a squared version of a city's median income will be added to the analysis we conduct below. This non-linear relationship is empirically supported as represented in Appendix A.

The impact of two additional socioeconomic factors will be considered in the analysis we conduct below, both of which focus on characteristics of the populations in U.S. cities on the U.S.-Mexico border. The first of these concerns the level of education that characterizes the population of cities in this region. The scholarly literature on socioeconomic resources and political behavior has shown that individuals with higher levels of resources, specifically, education and income, are more likely to overcome collective action barriers and participate in the political process and advocate for their interests [41,42]. This scholarship is relevant for citizens taking action on environmental problems because, as Jepson [24] and Kwon, Jang, and Feiock [26] have shown, cities with a greater percentage of college-educated citizens are more likely to influence local government's pursuit of environmental actions. Research also shows that cities with a greater percentage of college-educated citizens are more likely to support environmental activism $[25,43]$. In addition, research on the impact of political and civic activism focused on the pursuit of sustainability policies find that residents with higher levels of education are likely to take issues of sustainability more seriously [4]. Moreover, the education levels of citizens have been found to be factors that directly influence how local government officials respond to sustainability efforts [2]. As a result, a city's level of education is known to be an important factor, allowing its leaders to pursue policies that would potentially lower levels of GHG.

The final socioeconomic factor considered in the analysis we conduct below is intended to distinguish U.S. transborder cities in terms of their racial and ethnic characteristics. There are two reasons for distinguishing our sample of cities along racial/ethnic lines, the first of which centers on the problem of environmental injustice whereby poorer, high minority or marginalized communities bear a disproportionate burden of environmental degradation [37] and, thus, end up with the most 
severe forms of environmental problems. In addition to this, the political behavior literature has shown that individual policy preferences are in many ways related to the racial and ethnic characteristics of respondents. As a result of this, a measure of a border city's ethnic and racial characteristics is included in the analysis.

Parallel with a border city's overall socioeconomic profile and population characteristics will be how distributed that city's population is geographically. Cities on the northern side of the U.S.-Mexico border are not only spread out over a very long border that covers 2,000 miles, they also represent a very broad range of cities in terms of acreage and population size, which combine to indicate how concentrated or spread out the citizens of a city are. This analysis takes the geographic distribution of a city's population into consideration when assessing different municipal efforts to reduce GHG emissions from vehicles.

\subsection{Politics, Policies, and the Reduction of Greenhouse Gas Emissions}

There is a second category of factors that we take into consideration in our analysis of what accounts for the various efforts that U.S. border cities have taken to reduce GHG emissions from vehicles. As U.S. cities in the border region continue to grow and develop, some have elected to become involved in collective efforts to address the deleterious aspects of global climate change and promote sustainable development. Becoming involved in collective efforts such as climate change networks leads communities to become engaged in policy actions to promote sustainability in their communities [43-45]. One such initiative that encourages local governments to commit to this type of policy action is ICLEI-Local Governments for Sustainability (formerly, the International Council for Local Environmental Initiatives). ICLEI is a sustainability network organization founded in 1990 by representatives from 43 countries. Shortly after ICLEI was founded, a campaign was launched-the Cities for Climate Protection (CCP)—that ended up as a replacement to the $\mathrm{Urban} \mathrm{CO}_{2}$ project [21].

Initially, six local governments partnered with ICLEI to collaborate and develop initiatives on reducing GHG emissions [46]. Today, ICLEI consists of over 1500 cities, towns, and regions, including more than 120 countries worldwide. In the United States, there are over 550 local governments that joined and committed themselves to promoting action on reducing the deleterious effects of global climate change. While only a small number of cities in the U.S.-Mexico border region are ICLEI members, taking note of such a membership is important because municipal members commit themselves to combatting global climate change by reducing GHG emissions. Finally, ICLEI fosters an atmosphere of cooperation and collaboration among the various levels of governments (i.e., state, county, local), and it foresees urbanization and economic development coexisting alongside with sustainable cities [21,47]. Considering these ICLEI efforts, we anticipate that, compared to nonmembers, border cities with an ICLEI membership will have taken a more active role in addressing climate change and, thus, will have lower levels of GHG emissions than nonmembers.

The next factor we consider is a city's form of government, specifically whether a city has a mayor-council form of government or a council-manager system. A vast body of research has examined the relationship between local form of government and policy preferences. Structural differences in local government have been found to influence how local policies are developed, adopted, and implemented. Studies on political institutions suggest that the influence of government structure on local policy processes is significant, since distinct forms of government produce different incentives and constraints for local policy makers [48-52]. This is significant since local officials have significant influence on the adoption and management of local policies [53]. As U.S. transborder cities continue to expand their role in sustainability efforts, form of government becomes a central factor in the policy process.

Two forms of government are often examined, mayor-council and council-manager. The mayor-council structure is comprised of an elected council and an elected mayor with varying degrees of administrative power. Since this form of government consists of elected officials, a primary goal for this form of government is political responsiveness [54-56]. In contrast to this, the council-manager structure 
consists of elected city council members who appoint a nonelected professional manager to execute the daily administrative operations of the city. The primary goal of the council-manager system is to increase efficiency and effectiveness in city government through day-to-day administrative processes [54-56]. The distinction between the two forms of government is significant, because divergent motivations exist for elected officials based on different government structures.

This work has shown that these institutional differences are important for understanding how local policies are developed, adopted, and implemented, which means that these differences are related to whether cities have a propensity to pursue efforts to reduce GHG emissions and other sustainability policies. Studies show that council-manager governments have a significant and positive influence on local government's pursuit of sustainability initiatives [18], like GHG reduction efforts. Research also suggests that council-manager governments have a significant and positive effect on the number of sustainability tools directed at governmental operations, but less of an effect towards community-based efforts [17]. Related to this, Opp, Osgood, and Rugeley [20] noted in their examination of factors that lead to the adoption and implementation of environmental policies at the local level that council-manager governments have a positive effect on sustainability policies. Moreover, Svara [21] found that council-manager governments are more likely to have joined ICELI, acknowledging their commitment to adopting sustainability initiatives.

The reason for these different outcomes rests with the managerial characteristics of the council-manager structure, which enables local governments to develop sustainability and GHG reduction policies from a more insulated position, that is, with less influence from external stakeholders than the mayor-council institutional arrangement. This is a result of the varying objectives and rationales that professional managers bring to city government when juxtaposed with the goals and interests of elected officials. As a result of this, a border city's form of government will have considerable influence on efforts to reduce GHG emissions. The expectation is that U.S. border cities with a council-manager structure will have considerable influence on the adoption and implementation of initiatives that lower GHG emissions.

Since we are examining the policy efforts of U.S. border cities to reduce GHG emissions from vehicles across four states, we must look at both specific municipal policies to reduce GHG emissions as well as any relevant policies enacted at the state level that would distinguish cities in one of our four states from each other. In this respect, the state of California is distinct from Texas, New Mexico, and Arizona when it comes to reducing GHG emissions from tailpipes. California's efforts to reduce emissions from vehicles began in 1959, when it became the first state to promulgate statewide standards for vehicular emissions. The effort continued when Ronald Reagan was governor when, in 1967, he and other state leaders created the California Air Resources Board (CARB), which was directed to reducing air pollution throughout the state. One target of the CARB was emissions from vehicles, and over time CARB actions led to California having the cleanest fuels and lowest polluting vehicles in the nation. Currently, the most important CARB initiative is its Zero Emission Vehicle Mandate, where the goal is for the state to have 1.5 million electric vehicles on the road by 2025. As a result of such policy initiatives, we expect that border cities in California will be distinct in their efforts to reduce GHG emissions from vehicular sources [57].

In addition to the policy efforts of the states of California, some U.S. cities in the transborder region have designed and implemented their own specific policies to reduce GHG emissions from vehicular sources. Some of these policies are spelled out in their Comprehensive Plans and, thus, are implemented by staff in the Community Planning Divisions of their respective Departments of Community Development. Other such efforts may be part of a city's overall conservation and sustainability efforts and, thus, may be the purview of another city department. For example, the City of Chula Vista, California, has a Conservation Division within its Economic Development Department, and it is in this division that the city has implemented a policy to reduce GHG emissions by encouraging alternative forms of transportation. This effort includes the city providing maps of alternative fuel stations and providing residents with opportunities to pursue alternative commute options so that 
drive times in the city will be reduced. We note here that many U.S. border cities have developed bicycle lanes within their boundaries to encourage cycling, but these have been identified primarily for recreational purposes but not as a deliberate policy to reduce vehicular traffic and the overall use of GHG producing automobiles. Chula Vista as well as nine other cities in our data have done this as part of a deliberate plan to reduce vehicular use so that GHG emissions from tailpipes can be reduced, and it is only these cities that we identify in the analysis we conduct below.

We took two additional steps to distinguish U.S. cities in the transborder region that took specific steps to reduce GHG emissions from vehicles. The first of these steps involved determining whether a city put together and implemented a Climate Action Plan. While modelled after the original Climate Action Plan put together and implemented by the Obama Administration in 2008, these municipal plans are varied in the policy actions they emphasize. Nonetheless, all of these plans have GHG calculations and a discussion of the methodology they will use to monitor the levels of GHG emissions that exist in their areas of operation [58]. The second additional step we took to distinguish the efforts of U.S. cities in the border region to reduce GHG emissions was to identify cities that have stand-alone departments that address environmental matters and sustainability. The best illustration of such a city is the City of Tucson, Arizona, which has a Department of Environmental Services as one of its principal city departments. This Department of Environmental Services is responsible for such actions as the management of waste collection and disposal, but it also has sections dedicated to improving environmental conditions as well as reducing GHG emissions [59].

\section{Materials and Methods}

The unit of analysis is U.S. transborder cities, and as discussed above, we are interested in accounting for the differential approaches employed by these cities on the U.S. side of the U.S.- Mexico region to reduce GHG emissions from vehicular sources. Although the inclusion of cities on the Mexico side of the border would be very desirable and would make this study of border cities more complete, this effort is limited to U.S. cities in the border region because of limitations in the availability of data for the indicators we include in our analysis. As a result, we initially identified 93 cities in four different U.S. states located within $100 \mathrm{~km}$ from the U.S.-Mexico border (AZ-12; CA-16; NM-11; and TX-54), but despite identifying 93 our analysis consists of 72 cases due to data limitations. In particular, eleven of 93 cities in our analysis did not have any reportable GHG data thus reducing the number of cases to 72. In addition, the city of San Diego is excluded from the analysis because its size skews the results. San Diego is excluded because of its population size of 1.3 million when compared to the other less populated cities in the analysis, and the transborder region is known for smaller populations often overlooked in the literature. Moreover, results of a Cook's D test also revealed that San Diego functions as an outlier which necessitated that we eliminate it from our models. However, we did run an additional model including San Diego which confirmed that San Diego does act as an outlier. Further details are discussed in the Results section.

Data on the dependent variable derives from the Center for Neighborhood Technology (CNT) website, which captures the actual amount of GHG in the atmosphere as measured by tons per acre [60]. Specifically, the dependent variable is derived from the Housing and Transportation Affordability Index $(\mathrm{H}+\mathrm{T})$ and is the GHG emissions from household vehicle use in 2010. This value is calculated using the modeled values for Vehicle Miles Traveled (VMT), a national average fuel efficiency, and an average emissions factor per gallon on gasoline. The per acre measure divides the total block group emissions by the total land acres in the block group. Although GHG is generated by other types of vehicles, such as freight, this study focuses on GHG emission from household vehicles. This is the main source of GHG emission in the region and is the only available GHG from the H\&T index. We collected both GHG per household and GHG per acre, but due to numerous missing variables in GHG per household we instead use GHG per acre with more robust data. The per acre measure divides the total block group emissions by the total land acres in the block group [59]. This provides a reliable method to calculate the GHG emissions associated with household vehicles. GHG emissions are a critical component in 
accounting for the differential approaches employed by cities on the U.S. side of the border to reduce GHG emissions from vehicular sources. The CNT data has been used in previous studies $[61,62]$, and we use the data provided by them. Since the dependent variable is a continuous variable, we employ an ordinary least square (OLS) model. Methodologically, regression analysis, specifically, linear regressions, has been used in studies examining local sustainability [63,64]. As Azeez et al. [65] point out, numerous studies conducting this type of research have used various statistical, regression, and artificial intelligence models to predict and simulate vehicular GHG emissions.

Data for the independent variables were taken from multiple sources. The first independent variable involves the relationship that exists between a city's income and its GHG emissions. We test our hypothesis on the non-linear relationship between income and GHG emissions by using median household income in each city (in thousand dollars) and by also using the square of median household income (in thousand dollars) (for instance, income squared and non-linear relationships have been examined by Dollar and Gatti [66]; Layard, Mayraz, and Nickell [67,68]). Income data are drawn from the 2010 U.S. Census. As discussed above, several other socioeconomic indicators have been shown to influence the policy efforts of border cities to reduce GHG from vehicular sources. The scholarly literature has shown that education levels are an important factor in these kinds of city policies, and we capture their impact in our analysis by including the percentage of a border city's residents who are 25 years or older and have a college degree. Data for this variable is derived from the 2010 U.S. Census. The variable we use to measure the racial/ethnic makeup of U.S. border cities is the percentage of non-Hispanic white residents in U.S. border cities, and we expect the value of this percentage to be inversely proportional to the level of GHG emissions in their respective areas. Clark, Millet, and Marshall [69] have shown that non-Hispanic white populations are more likely to live in areas that are characterized by less environmental degradation, and this leads to our expectation about the relationship and levels of GHG emissions surrounding a border city. Data for this measure was taken from the 2010 Population Census.

The final socioeconomic variable included in our analysis is focused on how concentrated or disbursed a border city's population is geographically. This is a city's population density, and data for this variable are collected from the 2010 Population Census. The expectation is that the densely populated cities is expected to face higher levels of environmental challenge and, thus, have higher levels of GHG emissions from vehicular sources.

We also take into consideration two selected political and policy variables that will help account for the differential efforts of U.S. border cities to reduce GHG. The first of these involves whether a city has membership in ICLEI. The variable is binary and is coded 1 for membership status and 0 otherwise. Data is available from the organization's members website [70]. While endogeneity may be an issue as high GHG emissions may propel a city to adopt ICLEI membership leading to emissions reductions [71], we do not test for endogeneity due to the lack of time series data and the limited number of cities who were ICLEI members between 2009 and 2010. As only two of five cities were ICLEI members prior to the period of observation it limits our ability to fully test for endogeneity. Data for a city's form of government was obtained via an examination of city government websites and telephone interviews with managers of local governments. City form of government is coded as 1 for council-manager and 0 for all other forms.

Four dummy variables are also included in the analysis to capture the impact of the political and policy factors. Three of these variables capture whether a border city had drafted and implemented a Climate Action Plan, maintained a separate city department of environmental services, and had designed and implemented a specific plan to reduce vehicular emissions through the promotion of alternative means of transportation. These border city characteristics were determined by examining the various city websites and then conducting interviews with selected city managers. Finally, state dummy variables are also included to capture, first, the impact of the State of California Air Resources Board's efforts to reduce vehicular emissions. We also conducted our analysis to determine the impact of being one of the three remaining states and how coefficients on our other factors changed for New 
Mexico, Arizona, and Texas. We understand that it may seem unnecessary to run two separate models with different dummy variables, but we chose to analyze our data this way for two important reasons. Firstly, as discussed above, we know that greenhouse gas emission reduction policies in California are different because of the more active state effort there, and having a model with a California dummy will allow us to capture this impact. If we simply report this model only, we are then operating on the assumption that there are no state differences with respect to the remaining states of Arizona, New Mexico, and Texas. In fact, this may be the case, but we chose to include a second model with dummies for these remaining states. Consequently, by proceeding this way we can investigate this possibility empirically and be more certain rather than risking the possibility that our analysis be weakened my assuming an outcome rather than investigating it in data analysis. Our empirical model is specified below and the descriptive statistics for the variables can be found in Appendix B.

GHG amount $=\beta_{0}+\beta_{1}$ (median income $)+\beta_{2}$ (median income squared $)+\beta_{3}$ (population density) $+\beta_{4}$ (white percentage $)+\beta_{5}$ (education level $)+\beta_{6}$ (form of government $)+\beta_{7}$ (ICLEI membership $)+$ $\beta_{8}($ climate action plan $)+\beta_{9}($ emission reduction plan $)+\beta_{10}($ environment department $)+\varepsilon$

\section{Results}

Our models were estimated using Ordinary Least Squares with robust standard errors to counter the heteroscedasticity detected in our data, and results are presented in Table 1. As revealed in the table, we estimated two separate models, one where we included the dummy variable for the State of California and the other where California was left out and the states of Arizona, New Mexico, and Texas were included as separate dummy variables. Concerning the California model, the regression $\mathrm{F}$ was significant at the $p<0.01$ level so we can assume that the estimates for the model's coefficients are statistically significant from zero. On the other hand, the Regression F for the remaining three-state model was not significant, which means we cannot assume that our coefficient estimates are significantly different from zero, even though dummy estimates as well as estimates for the other variables were similar across these two models.

To get around the statistical weaknesses of the non-California model, we estimated three more models, one for each of the three remaining non-California states. The Regression Fs for the New Mexico and Texas estimates were not statistically significant, indicating that coefficient estimates for the models with these two state dummies may not be statistically different from zero. On the other hand, the regression F for the Arizona model was significant at the 95\% level of confidence. Despite these differences, results in these three models were similar in terms of the impact of a border city's median income and whether it has devised and implemented a specific plan to reduce GHG emissions. Coefficients were nearly identical across these three models, and they were also similar to the results produced in the non-California model in Table 1. Given these results, we focus on Table 1 which tell us about the differential efforts of border cities to reduce GHG emissions from vehicular sources.

Several of our expectations for which factors would be important in reducing actual levels of GHG emissions came from existing scholarship that focused on larger cities outside the U.S.-Mexico border region. Several of these expectations were not upheld in our analysis of the policy actions of U.S. border cities. Specifically, education levels, population densities, and the percentage of non-Hispanic whites in a city did not have a statistically significant impact on a border city acting to reduce its level of GHG emissions from vehicular sources. Again, these three socioeconomic variables have been found to be substantively and statistically significant in studies of larger city policy actions. The one socioeconomic factor that was important was a city's median income. Our results support the complicated relationship that we discussed above with respect to income and levels of GHG emissions. The coefficient was positive and statistically significant, indicating that wealthier cities in the U.S.-Mexico border region generally have higher levels of GHG emissions from vehicular sources. Also, while not statistically significant, the sign on this value squared was in the correct direction, indicating that the marginal impact of increasing city income declines as incomes rise. 
Table 1. Explaining border city efforts to reduce greenhouse gas emissions: results of ordinary least square (OLS) analyses.

\begin{tabular}{|c|c|c|}
\hline & California & Non-California \\
\hline Median Income & $\begin{array}{l}0.3963^{* *} \\
(2.06)\end{array}$ & $\begin{array}{c}0.3315^{*} \\
(1.74)\end{array}$ \\
\hline Median Income Squared & $\begin{array}{l}-0.0026 \\
(-1.35)\end{array}$ & $\begin{array}{l}-0.0019 \\
(-1.06)\end{array}$ \\
\hline Population Density & $\begin{array}{l}-0.0007 \\
(-1.52)\end{array}$ & $\begin{array}{l}-0.0004 \\
(-1.32)\end{array}$ \\
\hline Non-Hispanic White \% & $\begin{array}{l}0.5150 \\
(1.20)\end{array}$ & $\begin{array}{c}0.4342 \\
(1.10)\end{array}$ \\
\hline Education Levels & $\begin{array}{l}-0.2776 \\
(-1.47)\end{array}$ & $\begin{array}{l}-0.2521 \\
(-1.17)\end{array}$ \\
\hline Form of Government & $\begin{array}{c}2.2176 \\
(1.32) \\
\end{array}$ & $\begin{array}{c}1.8530 \\
(1.32) \\
\end{array}$ \\
\hline $\begin{array}{c}\text { ICLEI Membership } \\
\text { (Local Governments for Sustainability) }\end{array}$ & $\begin{array}{l}-2.2465 \\
(-1.11)\end{array}$ & $\begin{array}{l}-2.3938 \\
(-1.14)\end{array}$ \\
\hline Climate Action Plan & $\begin{array}{l}5.3787^{* * *} \\
(2.88)\end{array}$ & $\begin{array}{l}4.9155^{* *} \\
(2.19)\end{array}$ \\
\hline Emissions Reduction Plan & $\begin{array}{l}-5.1286 * * \\
(-2.48)\end{array}$ & $\begin{array}{l}-4.8971 \text { ** } \\
(-2.05)\end{array}$ \\
\hline Separate Environmental Dept & $\begin{array}{l}-2.45 .1^{*} \\
(-1.64)\end{array}$ & $\begin{array}{l}-1.8775 \\
(-1.20)\end{array}$ \\
\hline California & $\begin{array}{c}-7.0348 * \\
(-1.81)\end{array}$ & \\
\hline Texas & & $5.8973 *(1.66)$ \\
\hline New Mexico & & $6.6320 *(1.70)$ \\
\hline Arizona & & $9.5458^{* *}(2.06)$ \\
\hline \multirow[t]{2}{*}{ Constant } & $\begin{array}{l}-1.0816 \\
(-0.30)\end{array}$ & $\begin{array}{l}-6.9603 \\
(-1.23)\end{array}$ \\
\hline & $\begin{array}{c}\mathrm{N}=72 \\
\text { R-Squared }=0.3177 \\
\text { Prob }>\mathrm{F}=0.0055\end{array}$ & $\begin{array}{c}\mathrm{N}=72 \\
\text { R-Squared }=0.3571 \\
\text { Prob }>\mathrm{F}=0.1369\end{array}$ \\
\hline
\end{tabular}

${ }^{*} p<0.1 ;{ }^{* *} p<0.05 ;{ }^{* * *} p<0.01$. Robust standard errors are in parentheses.

While we would expect a city's economic wherewithal to be an important factor, the relationship between median income and GHG reduction efforts is complicated when we examine this relationship in border cities. This complicated relationship may be because these cities are unique in their level and pattern of economic development. Specifically, when the economic structure of border cities is not advanced, and accordingly income levels are low, increases in income will add to the output of GHG emissions from vehicles. However, once income levels increase to a higher threshold, environmental sustainability is perceived by residents to be a more important policy goal. In other words, the implications are twofold: firstly, early economic development stages result in negative environmental conditions, but as economic development begins to flourish and income increases, environmental degradation decelerates. Secondly, in the U.S. transborder region, many of the cities in this analysis are still experiencing population and industrial growth and, consequently, environmental degradation, which creates a complex situation for local governments who want to adopt GHG reduction policies. We suspect that until population and industrial development reaches a certain high point in a border city, a lack of GHG reduction policies will be the norm and emission levels will remain high.

Our results were also somewhat unexpected in terms of the impact of some of the policy and political variables that we included in the analysis. Firstly, while its sign was negative and in the expected direction, a city having an ICLEI membership did not lead to reduced GHG emissions in a statistically significant manner. This may be the result of the fact that there are only two ICLEI members among U.S. border cities. In addition to this, having a council-manager form of government 
was not statistically significant, and its sign was positive and, thus, not in the expected direction. While the literature is clear in that sustainability policies, such as those directed to reducing GHG emissions, are more likely to occur under a council-manager form of government, it is clear that leaderships in U.S. border cities are facing different imperatives that render this institutional difference not substantively important for their efforts to implement certain environmental policies. This, in fact, may derive out of the collective action all forms of government face in taking any policy action to improve environmental conditions.

Given the results presented so far, the remaining question is: what then accounts for whether a city on the U.S. side of the Mexican border will take specific action to reduce GHG emissions from vehicular sources? Our results indicate that four additional factors help explain levels of GHG emissions in the air surrounding our U.S. border cities. Three of these factors had coefficients in the expected direction that were statistically significant, while the fourth variable was statistically and substantively important but resulted in a coefficient with a sign in an unexpected direction. This factor rested on whether a border city had prepared and implemented a Climate Action Plan. Our expectation was that taking the time to prepare and implement a climate action plan would be associated with lower levels of GHG emissions from vehicular sources, but our analysis revealed that the opposite was true. Indeed, U.S. border cities that completed and implemented Climate Action Plans were associated with higher levels of GHG from vehicles.

Three factors appear relevant for understanding why cities that prepared and implemented Climate Action Plans were also those with high levels of vehicular GHG emissions. The first is simply that, while only a small number of border cities designed and implemented Climate Action Plans, the ones that followed this policy path were most likely to be border cities with higher levels GHG emissions. The second reason for this result is related to the previous explanation in that the Climate Actions Plans that were designed and implemented by U.S. border cities have not been in effect long enough to have had a measurable impact on the air of cities that followed this policy path. Recall from the above discussion that the impetus for putting together Climate Action Plans was implemented by the Obama Administration in 2008. Given the timing of our data, the implemented Climate Action Plans we noted would not have been in effect long enough to have had a measurable impact on reducing levels of GHGs in the atmospheres of the border cities that implemented them. Finally, Climate Action Plans are comprehensive policy documents that involve more than GHG emissions from vehicular sources, which means that they may have a positive impact on some aspects of the global climate change problems but not on the specific problem we are investigating in this research.

The remaining factor with the largest, statistically significant impact on GHG emissions from vehicular sources was a border city having a specific plan to reduce vehicular use and the pollution that comes from vehicles. The other two factors, the State of California with its unique policies to encourage the use of electric vehicles and a border city having a stand-alone environmental services department, were both associated with lower levels of actual GHG emission levels from vehicular sources. While coefficients on these two explanatory variables were substantively significant, their statistical significance was at the $p<0.10$ level. Overall, these results tell us that state policy action is important but that even when cities act alone, they can have a significant impact on reducing actual levels of GHG emissions from automobiles and trucks. These are important findings because they tell us that the structural (socioeconomic) characteristics of cities are less important than possession of the political will simply to implement the policies necessary to grapple with the deleterious effects of global climate change. This is true even when cities face disincentives from taking such policy action as do our cities on the U.S. side of the Mexican border.

Although we do not report San Diego in our results, we did run an additional model including San Diego and found the results to be consistent with our main model that excluded San Diego. One difference was found in the median income variable that was not statistically significant in the model that included San Diego. It could be that the median income in San Diego is higher when compared to other border cities, which makes it difficult to maintain a consistent comparison between 
border cities. In addition, San Diego is the second largest city in the U.S. that borders another country; its population size and land area (square miles) are also not reflective of other U.S. border cities in this analysis.

\section{Discussion}

This study finds that state policy action is important in reducing GHG from vehicular sources, indeed, just as significant as are actions from transborder cities themselves to address emissions from vehicular sources. Transborder cities in the U.S. share climate change issues such as GHG emissions from vehicular sources that make it difficult to act to counter the damaging impact of global climate change. Although, transborder cities share similar characteristics such as poor ecological environments, continued economic development and industrialization, and factors that directly impact the level of environmental sustainability, policy action challenges exist across an international divide. Combating GHG emissions from vehicular sources is a complicated endeavor when one of the member states or city has a policy action disincentive to address vehicular emission concerns. This problem is further amplified by the fact that both sides of the border have large industrial urban areas as well as small rural cities that have competing interests, both economically and environmentally. In other words, because GHG emissions are transboundary it will take efforts from cities on both sides of the U.S.-Mexico border to address emission concerns from vehicular sources in the transborder region. As Klein [72] suggests, until there is a consensus of good faith actions to address climate change between developed and developing countries, policy challenges will continue. While GHG in general are transboundary and a global issue by nature, communities in the U.S. border region are directly impacted by vehicular emissions due to cross-border trade that is not prevalent in interior communities. Along this same line of research, Alzard et al. [73] found that in 2016 the transport sector was responsible for the second largest amount of GHG emissions and that road transport was projected to continue to grow. Thus, as Pindyck [74] asks, after a cost benefit analysis of implementing an environmental policy, is a climate policy even worth adopting?

In spite of the complications we uncovered, this analysis made three theoretical contributions to the extant literature. Firstly, this study contributes to an area that has not received much attention in the literature: what accounts for whether a U.S. city on the U.S.- Mexico border will take specific action to reduce GHG emissions from vehicular sources. While numerous studies have examined larger interior U.S. cities and their efforts to reduce GHGs, we contribute to the literature by examining an area often overlooked in the scholarly literature: cities in the U.S. transborder region. These cities are distinct in terms of their geographic location (i.e., they share a border with a less developed country), respective social and economic profiles, traditions, cultures, and policy priorities. Several factors appear relevant for understanding why U.S. transborder cities prepare and implement emission plans. U.S. transborder cities who adopted and implemented Climate Action Plans were most likely to have higher levels of GHG emissions. This result is related to when the Climate Actions Plans were designed and implemented. Given the timing of our analysis, the implemented Climate Action Plans would not have been in effect long enough to have had a measurable impact on reducing levels of GHG in the atmospheres of the border cities that implemented them. As stated above, Climate Action Plans are comprehensive policy documents that involve more than GHG emissions from vehicular sources, which means that they may have a positive impact on some aspects of the global climate change problems but not on the specific problem we are investigating in this research.

A second contribution of this analysis centers on factors that are important in reducing actual levels of GHG emissions. When compared to prior scholarship, which has focused on larger cities outside the U.S.-Mexico border region, socioeconomic variables are typically substantively and statistically significant in studies of policy actions. Several of these findings were not upheld in our analysis of the policy actions of U.S. border cities. Education levels, population densities, and the percentage of non-Hispanic whites in a city did not have a statistically significant impact on a border city acting to reduce its levels of GHG emissions from vehicular sources. The implications of these findings seem 
to support the argument that transborder cities and interior U.S. cities may have divergent climate action initiatives for addressing vehicular emissions. The third contribution of this analysis is that the present study examines sustainability efforts for U.S. border communities overlooked by the ICMA or other regional and national surveys. The present study is one of a few to examine social and political (policy) factors that impact levels of GHG emissions from vehicular sources exclusive to the U.S. transborder region.

\section{Limitations and Areas for Further Development}

This study examined whether a U.S. city on the U.S.- Mexico border will take specific action to reduce GHG emissions from vehicular sources. We focused on social and political factors that impact levels of GHG emissions in transborder cities. With this in mind, we also recognize existing limitations with our research. Firstly, analyzing a single year of data can be problematic in generalizing our findings; one year of data may have overlooked factors which may have affected GHG emissions from vehicular sources. For example, causal factors such as miles traveled within cities and fuel prices may have led to changes in travel patterns resulting in lower or higher vehicular GHG emissions, which has the potential of leading to a discussion on causation or correlation in the reduction of GHG emissions; this is an area for additional scholarly attention. Additionally, our analysis was limited to one year of observations due to the lack of available GHG emission data. Secondly, the CNT data used in this analysis only accounts for household vehicles and does not include freight, agriculture, or other off-road vehicles. This challenge is an area ripe for future research. In addition, there are several other variables that could have been tested in this analysis, but the lack of data specific to the transborder region proved challenging. For example, while cross-border trade is a common occurrence in the U.S.-Mexico transborder region, not all the cities in the analysis are located directly at a border point of entry. A third limitation is the lack of available environmental data for individual U.S. transborder cities. Although the U.S. and Mexico acknowledge the need for more transparency in data collection that directly affects the transborder region, to date, data on the transborder region is isolated to large metropolitan areas such as San Diego, CA and Tucson, AZ. Nevertheless, this study is the first step in bridging the gap between large metropolitan areas and lesser known communities such as Desert Shores, CA, La Union, NM, and Valentine, TX. Future studies need to develop alternative approaches and expanded data on such GHG reduction efforts in order to provide a more nuanced examination of some of the challenges or successes in the U.S. transborder region.

\section{Conclusions}

Several key findings and implications can be taken from this study. In the U.S. transborder region, the relationship between median income and GHG reduction efforts is complicated. The economic structure of some cities in the U.S. transborder region are not advanced, levels of low income and education continue to exist, and because of this an increase in income will add to the output of GHG emissions from vehicular sources. However, once income levels increase to a certain threshold, issues of environmental sustainability are seen as important policy goals for residents. The implications are significant on two fronts. First and simply stated, early stages of economic development result in negative environmental conditions, however as economic development becomes robust and income increases, negative environmental conditions decelerate. Secondly, in this analysis, many cities in the U.S. transborder region are still experiencing population growth and economic development resulting in negative environmental conditions. This scenario creates complex issues for local governments who want to adopt and (or) implement GHG reduction policies. We anticipate that until population growth and economic development reach their highest points, a lack of GHG mitigation policies will adopted and emission levels will remain high. These complex implications seem to support the argument that transborder cities and interior U.S. cities may have divergent climate action initiatives for addressing vehicular emissions. 
While the results from this study are informative, the implications of the findings also raise questions that lend themselves to future research. Indeed, if it is a matter of political will at both state and local levels that produces policies to lower actual levels of GHG emissions from vehicular sources—or any other sources for that matter-then it would be worth understanding why some cities and states possess that will and not others. Furthermore, the U.S.-Mexico transborder region is known for its large Latino population and additional empirical studies are needed to further examine GHG emissions from vehicular sources in predominately Latino regions in the U.S. This is another area that is underdeveloped in the academic literature. Finally, while this study focuses on the individual city level, future studies should also consider more dynamic characteristics such as spatial autocorrelation. While this will have to be the subject of future research, we hope that the research we completed in this study will be an informative basis for this future research.

Author Contributions: All authors have contributed to the intellectual content of this paper. Conceptualization, S.G.G.; methodology, D.P. and S.W.K.; software, D.P.; validation, D.P., S.W.K. and S.G.G.; formal analysis, D.P.; investigation, S.G.G.; resources, S.G.G.; data duration, S.G.G.; writing-original draft preparation, S.G.G., S.W.K., and D.P. writing - review and editing, S.G.G.; S.W.K. and D.P. supervision, S.G.G.; project administration, S.G.G.

Funding: This research received no external funding.

Acknowledgments: We would like to thank Daehee Bak for his valuable comments on our research design and empirical analysis.

Conflicts of Interest: The authors declare no conflict of interest.

\section{Appendix A}

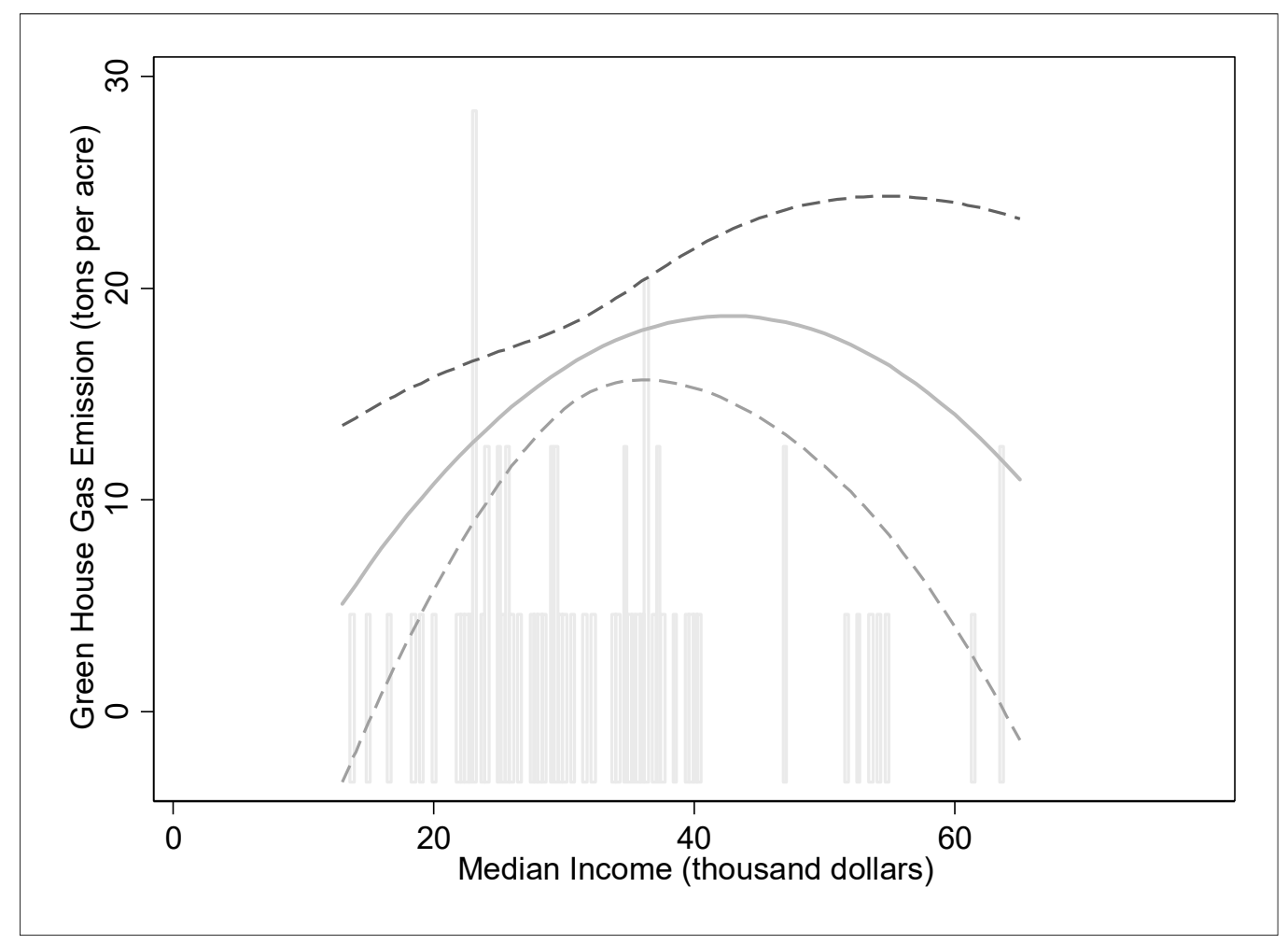

Figure A1. The Effect of Median Income on GHG Emissions in Trans-Border Cities without an Outlier City. Note: The dashed lines represent the $95 \%$ confidence intervals. 


\section{Appendix B}

Table A1. Descriptive Statistics for Dependent and Independent Variables.

\begin{tabular}{|c|c|c|c|c|c|}
\hline Variable and Description & $\mathbf{N}$ & Mean & Std. Dev & Min & Max \\
\hline $\begin{array}{c}\text { GHG amount (tons, per acre) } \\
\text { Source: Center for Neighborhood Technology (CNT) }\end{array}$ & 74 & 14.63 & 11.16 & 0.01 & 49.47 \\
\hline $\begin{array}{l}\text { Median household income (in thousand dollars) } \\
\text { Source: American FactFinder, } 2010 \text { Census-U.S. } \\
\text { Census Bureau }\end{array}$ & 86 & 33.33 & 12.90 & 13.58 & 81.95 \\
\hline $\begin{array}{l}\text { Median household income square (in thousand dollars) } \\
\text { Source: American FactFinder, } 2010 \text { Census-U.S. } \\
\text { Census Bureau }\end{array}$ & 86 & 1275.85 & 1084.76 & 184.63 & 6715.96 \\
\hline $\begin{array}{l}\text { Population density (population per square miles) } \\
\text { Source: American FactFinder, } 2010 \text { Census-U.S. } \\
\text { Census Bureau }\end{array}$ & 85 & 1997.03 & 1791.00 & 18.25 & 12894.44 \\
\hline $\begin{array}{l}\text { Non-Hispanic white population (\% of non-Hispanic } \\
\text { resident) } \\
\text { Source: American FactFinder, } 2010 \text { Census-U.S. } \\
\text { Census Bureau }\end{array}$ & 87 & 3.18 & 4.90 & 0 & 28.37 \\
\hline $\begin{array}{c}\text { Education levels (\%, residents } 25 \text { years of older with } \\
\text { bachelor's degree or above) } \\
\text { Source: American FactFinder, } 2010 \text { Census-U.S. } \\
\text { Census Bureau }\end{array}$ & 86 & 9.32 & 6.28 & 0 & 33 \\
\hline $\begin{array}{l}\text { Form of government }(1=\text { council-manager form, } \\
\quad 0=\text { others }) \\
\text { Source: City Websites and Interviews with City Managers }\end{array}$ & 92 & 0.40 & 0.49 & 0 & 1 \\
\hline $\begin{array}{l}\text { ICLEI membership }(1=\text { membership, } 0=\text { no membership }) \\
\text { Source: ICLEI Local Governments for } \\
\text { Sustainability website }\end{array}$ & 92 & 0.05 & 0.22 & 0 & 1 \\
\hline $\begin{array}{c}\text { Climate Action Plan }(1=\text { yes, } 0=\text { no }) \\
\text { Source: City Websites and Interviews with City Managers }\end{array}$ & 92 & 0.543 & 0.22 & 0 & 1 \\
\hline $\begin{array}{l}\text { Emissions Reduction Plan }(1=\text { yes, } 0=\text { no }) \\
\text { Source: City Websites and Interviews with City Managers }\end{array}$ & 92 & 0.097 & 0.29 & 0 & 1 \\
\hline $\begin{array}{l}\text { Separate Environmental Department }(1=\text { yes, } 0=\text { no }) \\
\text { Source: City Websites and Interviews with City Managers }\end{array}$ & 92 & 0.076 & 0.26 & 0 & 1 \\
\hline
\end{tabular}

\section{References}

1. Bloomberg, M. City century: Why municipalities are key to fighting climate change. Foreign Aff. 2015, 94, 60-72. Available online: https://www.foreignaffairs.com/articles/2015-08-18/city-century (accessed on 27 June 2019).

2. Portney, K.E. Taking Sustainable Cities Seriously: Economic Development, the Environment, and Quality of Life in American Cities; MIT Press: Cambridge, MA, USA, 2003.

3. Portney, K.E. Sustainability in American cities: A comprehensive look at what cities are doing and why. In Toward Sustainable Communities: Transition and Transformations in Environmental Policy, 2nd ed.; Mazmanian, D.A., Kraft, M.E., Eds.; MIT Press: Cambridge, MA, USA, 2009; pp. 227-254.

4. Portney, K.E.; Berry, J.M. Participation and the pursuit of sustainability in U.S. cities. Urban Aff. Rev. 2010, 45, 119-139. [CrossRef]

5. Gerber, J.; Lara-Valencia, F.; de la Parra, C. Re-Imagining the U.S.-Mexico border: Policies toward a more competitive and sustainable transborder region. Glob. Econ. J. 2010, 10, 1-17. [CrossRef]

6. U.S. Dept of Transportation, Bureau of Transportation Statistics. Border Crossing Entry Data. Available online: https://www.bts.gov/content/border-crossingentry-data (accessed on 27 June 2019).

7. Liverman, D.M.; Vardy, R.G.; Chavez, O.; Sanchez, R. Environmental issues along the United States-Mexico border: Drivers of change and responses of citizens and institutions. Annu. Rev. Energy Environ. 1999, 24, 607-643. [CrossRef] 
8. Bennet, V.; Herzog, L.A. U.S.-Mexico borderland water conflicts and institutional change: A commentary. Nat. Resour. J. 2000, 40, 973-988. Available online: https://digitalrepository.unm.edu/nrj/vol40/iss4/9 (accessed on 27 June 2019).

9. Mumme, S.P.; Collins, K. The La Paz Agreement 30 years on. J. Environ. Dev. 2014, 23, 303-330. [CrossRef]

10. Licón, C.V.; Balarezo, T. Municipal sustainable development possibilities along the US-Mexico Border: An interdisciplinary evaluation effort. Rev. Int. de Sostenibilidad Tecnol. Humanismo 2009, 4, 98-113. Available online: http://hdl.handle.net/2099/8537 (accessed on 27 June 2019).

11. Wilder, M.; Scott, C.A.; Pineda Pablos, N.; Varady, R.G.; Garfin, G.M.; McEvoy, J. Adapting across boundaries: Climate change, social learning, and resilience in the U.S.-Mexico border region. Ann. Assoc. Geogr. 2010, 100, 917-928. [CrossRef]

12. U.S. Environmental Protection Agency Office of International and Tribal Affairs and Secretaría de Medio Ambiente y Recursos Naturales (SEMARNAT). Border 2020: U.S.-Mexico Environmental Program; U.S. Environmental Protection Agency Office of International and Tribal Affairs and Secretaría de Medio Ambiente y Recursos Naturales: Washington, DC, USA, 2012.

13. Calavita, K. Inside the State: The Bracero Program, Immigration, and the I.N.S.; Routledge: New York, NY, USA, 1992.

14. Quesada, J.A.; Sanchez, H. PwC-IMMEX Maquiladora Guide Doing Business in Mexico; Price Waterhouse Cooper: London, UK, 2013.

15. World Commission on Environment and Development (WECD). Our Common Future; Oxford University Press: New York, NY, USA, 1987.

16. Hempel, L. Conceptual and analytical challenges in building sustainable communities. In Toward Sustainable Communities: Transition and Transformations in Environmental Policy, 2nd ed.; Mazmanian, D., Kraft, M., Eds.; MIT Press: Cambridge, MA, USA, 2009; pp. 33-62.

17. Bae, J.; Feiock, R.C. Managing multiplexity: Coordinating multiple services at a regional level. State Local Gov. Rev. 2012, 44, 162-168. [CrossRef]

18. Feiock, R.C.; Francis, N.; Kassekert, T. Explaining the Adoption of Climate Change Policies in Local Government. Low Carbon Cities Workshop. 2010. Available online: http://citeseerx.ist.psu.edu/viewdoc/ download?doi=10.1.1.470.4620\&rep=rep1\&type=pdf (accessed on 27 June 2019).

19. Lubell, M.; Feiock, R.C.; Ramirez de la Cruz, E.E. Local institutions and the politics of urban growth. Am. J. Political Sci. 2009, 53, 649-665. [CrossRef]

20. Opp, S.M.; Osgood, J.L.; Rugeley, C.R. Explaining the adoption and implementation of local environmental policies in the United States. J. Urban Aff. 2013, 36, 854-875. [CrossRef]

21. Svara, J.H. The early stage of local government action to promote sustainability. In The Municipal Year Book 2011; International City County Management Association: Washington, DC, USA, 2011; pp. 43-60.

22. Lubell, M.; Feiock, R.; Handy, S. City adoption of environmentally sustainable policies in California's central valley. J. Am. Plan. Assoc. 2009, 75, 293-308. [CrossRef]

23. Saha, D.; Paterson, R. Local government efforts to promote the "three Es" of sustainable development: Survey in medium to large cities in the United States. J. Plan. Educ. Res. 2008, 28, 21-37. [CrossRef]

24. Jepson, E.J., Jr. The adoption of sustainable development policies and techniques in U.S. cities how wide, how deep, and what role for planners? J. Plan. Educ. Res. 2004, 23, 229-241. [CrossRef]

25. Krause, R.M. Policy innovation, intergovernmental relations, and the adoption of climate protection initiatives by U.S. cities. J. Urban Aff. 2011, 33, 45-60. [CrossRef]

26. Kwon, M.; Jang, H.S.; Feiock, R.C. Climate protection and energy sustainability policy in California cities: What have we learned? J. Urban Aff. 2014, 36, 905-924. [CrossRef]

27. Fitzgerald, J. Emerald Cities: Urban Sustainability and Economic Development; Oxford University Press: New York, NY, USA, 2010.

28. Sharp, E.B.; Daley, D.M.; Lynch, M.S. Understanding local adoption and implementation of climate change mitigation policy. Urban Aff. Rev. 2011, 47, 433-457. [CrossRef]

29. Wang, X.H.; Hawkins, C.V.; Lebredo, N.; Berman, E.M. Capacity to sustain sustainability: A study of U.S. cities. Public Adm. Rev. 2012, 72, 841-853. [CrossRef]

30. U.S. Environmental Protection Agency. Environmental Justice. Available online: https://www.epa.gov/ environmentaljustice (accessed on 27 June 2019). 
31. Canas, J.; Coronado, R.; Gilmer, R.W.; Saucedo, E. The impact of the maquiladora industry on U.S. border cities. Growth and Chang. A J. Urban Reg. Policy 2013, 44, 412-442. [CrossRef]

32. Heerink, N.; Mulatu, A.; Bulte, E. Income inequality and the environment: Aggregation bias in environmental Kuznets curves. Ecol. Econ. 2001, 38, 359-367. [CrossRef]

33. Millimet, D.L.; List, J.A.; Stengos, T. The environmental Kuznets curve: Real progress or misspecified models? Rev. Econ. Stat. 2003, 85, 1038-1047. [CrossRef]

34. Torras, M.; Boyce, J.K. Income, inequality, and pollution: A reassessment of the environmental Kuznets curve. Ecol. Res. 1998, 25, 147-160. [CrossRef]

35. Magnani, E. The environmental Kuznets curve, environmental protection policy and income distribution. Ecol. Econ. 2000, 32, 431-443. [CrossRef]

36. Lee, E.; Wilson, C.E.; Lara-Valencia, F.; de la Parra, C.A.; Van Schoik, R.; Patron-Soberano, K.; Olson, E.L.; Selee, A. The State of the Border Report a Comprehensive Analysis of the U.S.-Mexico Border; Wilson, C.E., Lee, E., Eds.; Mexico Institute and Woodrow Wilson International Center for Scholars: Washington, DC, USA, 2013.

37. Bullard, R.D. Unequal Protection: Environmental Justice and Communities of Color; Sierra Club Books: San Francisco, CA, USA, 1997.

38. Bullard, R.D.; Mohai, P.; Saha, R.; Wright, B. Toxic Waste and Race at Twenty 1987-2007; United Church of Christ Justice \& Witness Ministries: Cleveland, OH, USA, 2007.

39. Olpadwala, P.; Goldsmith, W.W. The sustainability of privilege: Reflections on the environment, the third world city, and poverty. World Dev. 1992, 20, 627-640. [CrossRef]

40. Pezzullo, P.C.; Sandler, R. Revisiting the environmental justice challenge to environmentalism. In Environmental Justice and Environmentalism the Social Justice Challenge to the Environmental Movement; Sandler, R., Pezzullo, P.C., Eds.; The MIT Press: Cambridge, MA, USA, 2007; pp. 1-24.

41. Brady, H.E.; Sidney, V.; Lehman Scholzman, K. Beyond SES: A resource model of political participation. Am. Political Sci. Rev. 1995, 89, 271-294. [CrossRef]

42. Leighley, J.E.; Vedlitz, A. Race, ethnicity, and political participation: Competing models and contrasting explanations. J. Politics 1999, 61, 1092-1114. [CrossRef]

43. O'Connell, L. Exploring the social roots of smart growth policy adoption by cities. Soc. Sci. Q. 2008, 89, 1356-1372. [CrossRef]

44. Hawkins, C.V.; Kwon, S.W.; Bae, J. Balance between local economic development and environmental sustainability: A multi-level governance perspective. Int. J. Public Adm. 2016, 39, 803-811. [CrossRef]

45. Krause, R.M. An assessment of the impact that participation in local climate networks has on cities' implementation of climate, energy, and transportation policies. Rev. Policy Res. 2012, 29, 585-604. [CrossRef]

46. Betsill, M.M. Mitigating climate change in US cities: Opportunities and obstacles. Local Environ. 2010, 6, 393-406. [CrossRef]

47. Francis, N.; Feiock, R.C. A Guide for Local Government Executives on Energy Efficiency and Sustainability; IBM Center for The Business of Government: Washington, DC, USA, 2011.

48. Carr, J.B. What have we learned about the performance of council-manager governments? A review and synthesis of the research. Public Adm. Rev. 2015, 75, 673-689. [CrossRef]

49. Clingermayer, J.C.; Feiock, R.C. Institutional Constraints and Policy Choice: An Exploration of Local Governance; State University of New York: Albany, NY, USA, 2001.

50. Feiock, R.C.; Jeong, M.G.; Kim, J. Credible commitment and council-manager government: Implications for policy instrument choices. Public Adm. Rev. 2003, 63, 616-625. [CrossRef]

51. Frant, H. High-power and low-power incentives in the public sector. J. Public Adm. Res. Theory 1996, 6, 365-381. [CrossRef]

52. Zhang, Y.; Feiock, R.C. City managers' policy leadership in council-manager cities. J. Public Adm. Res. Theory 2010, 20, 461-476. [CrossRef]

53. Elkin, S.L. City Regime in the American Republic; University of Chicago Press: Chicago, IL, USA, 1987.

54. Feiock, R.C.; Kim, J.H. Form of government, administrative organization, and local economic policy. J. Public Adm. Res. Theory 2001, 11, 29-49. [CrossRef]

55. Frederickson, H.G.; Johnson, G.A.; Wood, C.H. The Adapted City: Institutional Dynamics and Structural Change; M.E. Sharpe: Armonk, NY, USA, 2004. 
56. Moulder, E.R. Municipal form of government: Trends in structure, responsibility, and composition. In The Municipal Year Book; International City/County Management Association: Washington, DC, USA, 2008; pp. 27-33.

57. California Air Resources Board. Available online: https://ww2.arb.ca.gov/homepage (accessed on 27 June 2019).

58. U.S. Department of Energy; Executive Office of the President. The President's Climate Action Plan; U.S. Department of Energy: Washington, DC, USA; Executive Office of the President: Washington, DC, USA, 2013. Available online: https://www.google.com/search?client=firefox-b-1-d\&q=2008+Climate+Action+ Plan+completed+by+the+Obama+Administration (accessed on 27 June 2019).

59. City of Tucson. Environmental Services. Available online: https://www.tucsonaz.gov/environmental-services (accessed on 27 June 2019).

60. Center for Neighborhood Technology. Housing + Transportation Affordability Index. Available online: http://www.cnt.org/tools/housing-and-transportation-affordability-index (accessed on 27 June 2019).

61. Hoornweg, D.; Sugar, L.; Trejos Gomez, C.L. Cities and greenhouse has emissions: Moving forward. Environ. Urban. 2011, 23, 207-227. [CrossRef]

62. Weigel, B.A.; Southworth, F.; Meyer, M.D. Calculators to estimate greenhouse gas emissions from public transit vehicles. Transp. Res. Rec. 2010, 2143, 125-133. [CrossRef]

63. Reis, C.; Lopes, A. Evaluating the cooling potential of urban green spaces to tackle urban climate change in Lisbon. Sustainability 2019, 11, 2480. [CrossRef]

64. Bergmann, A.; Posch, P. Mandatory sustainability reporting in Germany: Does size matter? Sustainability 2018, 10, 3904. [CrossRef]

65. Azeez, O.S.; Pradhan, B.; Shafi, H.Z.M. Vehicular CO emission prediction using support vector regression model and GIS. Sustainability 2018, 10, 3434. [CrossRef]

66. Dollar, D.; Gatti, R. Gender Inequality, Income, and Growth: Are Good Times Good for Women? (In English). The World Bank: Washington, DC, USA, 1999. Available online: http://documents.worldbank.org/curated/ en/251801468765040122/Gender-inequality-income-and-growth-are-good-times-good-for-women (accessed on 27 June 2019).

67. Layard, R.; Mayraz, G.; Nickell, S. The marginal utility of income. J. Public Econ. 2008, 92, $1846-1857$. [CrossRef]

68. Layard, R.; Mayraz, G.; Nickell, S. Does relative income matter? Are the critics right. In International Differences in Well-Being; Diener, E., Helliwell, J.F., Kahneman, D., Eds.; Oxford University Press: New York, NY, USA, 2010; pp. 139-165.

69. Clark, L.P.; Millet, D.B.; Marshall, J.D. National patterns in environmental injustice and inequality: Outdoor $\mathrm{NO}_{2}$ air pollution in the United States. PLOS ONE 2014, 9, e94431. [CrossRef] [PubMed]

70. ICLEI. Local Government for Sustainability, Who We Are. Available online: http://www.iclei.org/about/whois-iclei.html (accessed on 27 June 2019).

71. Yi, H.; Krause, R.M.; Feiock, R.C. Back-pedaling or continuing quietly? Assessing the impact of ICLEI membership termination on cities' sustainability actions. Environ. Politics 2017, 26, 138-160. [CrossRef]

72. Klein, R.J.T. Mainstreaming climate adaptation into development: A policy dilemma. In Climate Governance and Development: Berlin Workshop Series 2010; Ansohn, A., Pleskovic, B., Eds.; World Bank: Washington, DC, USA, 2011; pp. 35-52.

73. Alzard, M.H.; Munjed, A.M.; Chowdhury, R.; Khan, Q.; Albuquerque, F.D.B.; Mauga, T.I.; Aljunadi, K.N. Estimation of greenhouse gas emissions produced by road projects in Abu Dhabi, United Arab Emirates. Sustainability 2019, 11, 2367. [CrossRef]

74. Pindyck, R.S. The Climate Policy; Dilemma; National Bureau of Economic Research: Cambridge, MA, USA, 2012; 18205p.

(C) 2019 by the authors. Licensee MDPI, Basel, Switzerland. This article is an open access article distributed under the terms and conditions of the Creative Commons Attribution (CC BY) license (http://creativecommons.org/licenses/by/4.0/). 